\title{
Highly Expression and Purification of an Antigenic Region (D259-R462) of Adenylate Guanylate Cyclase Protein, Applicable for ELISA Test
}

Jeyran Ghalani ${ }^{2}$

https://orcid.org/0000-0001-5842-4146

\author{
Majid Esmaelizad ${ }^{1^{*}}$ \\ https://orcid.org/0000-0001-8527-784x
}

Kimia Kamalzadeh ${ }^{2}$

https://orcid.org/0000-0001-9537-4512

\begin{abstract}
${ }^{1}$ Central Laboratory Department, Razi Vaccine and Serum Research Institute, Agricultural Research, Education and Extension Organization (AREEO), Karaj, Alborz, Iran; ${ }^{2}$ Islamic Azad University, Science and Research Branch, Tehran, Iran.
\end{abstract}

Editor-in-Chief: Paulo Vitor Farago

Associate Editor:Marcelo Ricardo Vicari

Received: 2020.07.25; Accepted: 2021.05.27.

${ }^{*}$ Correspondence: m.esmaelizad@rvsri.ac.ir; Tel.: +98-912-738-3082 (M.E.).

\section{HIGHLIGHTS}

- This is first study to present AGC protein as a candidate antigen in ELISA.

- High yield $514.2 \mathrm{mg}$ purity of recombinant protein.

- Urea purification method is a simple and low-cost with high efficiency technique which has been used in this research.

- rAcB demonstrating that might be useful for evaluation of antibody level in vaccinated animal.

Abstract: Leptospirosis is a wide spread bacterial zoonosis that is common worldwide. The disease symptoms are mild or acute. Leptospira has pathogenic and non-pathogenic species; it has a lot of surface antigens. Adenylate Guanylate Cyclase (AGC) is a membrane protein that is found only in pathogenic species. In this study, the complete coding sequences of AGC protein of 242 pathogen serovars were investigated by bioinformatics tools. A Pattern was selected as a target sequence based on high prevalence pathogenic serovars in Iran Antigen sites; moreover, B-cell and T-cell epitopes were predicted by IEDB web server. An antigen site amino acid (D259-R462) in complete coding sequence of AGC protein was selected. This nucleotide related sequence was cloned into the $\mathrm{pET} 32 \mathrm{a}+$ expression vector. Expression of recombinant protein was optimized in E. coli strain BI21-DE3 by $0.2 \mathrm{mM}$ IPTG after 16 -hour incubation at $37 \circ \mathrm{C}$ and confirmed by $10 \%$ SDS-PAGE and western blotting. Antigenic peptide D259-R462 was highly expressed as $T r x$ tag fusion protein. Recombinant peptide ( $\mathrm{rAcB}$ ) was purified by $6 \mathrm{M}$ urea from inclusion body with high extent yield $514.2 \mathrm{mg}$ per $1000 \mathrm{ml}$ culture of E. coli. $20 \mu \mathrm{g}$ rAcB protein with montanide adjuvant was injected subcutaneously in BALB/c mice. Results showed that the recombinant peptide D259-R462 was produced 
significant antibody compared to adjuvant and PBS groups. The induced antibody in sera of immunized animal with Leptospira vaccine was detected by $250 \mathrm{ng}$ of $\mathrm{rAcB}$ coated in ELISA microplate. This study demonstrated that antigenic region (D259-R462) of AGC protein might be useful for evaluation of antibody level in vaccinated animal.

Keywords: AGC; Leptospirosis; Recombinant protein.

\section{INTRODUCTION}

Leptospirosis is wide spread zoonosis bacterial disease caused by Leptospira spirochetes that is common all over the word [1,2]. This bacterium needs a humid environment to grow and survives in a muddy environment for months. The persistence of this bacterium in water depends on the salt concentration, $\mathrm{pH}$ and viscosity $[3,4]$. Both of non-pathogen (biflexa serovar) and pathogenic (interrogans) species belong to the Leptospira genus [5]. The Leptospira was isolated from different hosts: mammals, birds, amphibians and reptiles [6,7]. Human infection is caused by direct contact with the urine of contaminated animals or indirectly through the water contamination [1]. Leptospirosis is an acute febrile illness that encompasses a wide range of symptoms or without indication [8]. Symptoms can be observed from a mild form similar to influenza to severe ones such as hemorrhage, jaundice, myalgia, renal impairment, and aseptic meningitis [8,2]. In the meantime Of course, most patients exhibit moderate symptoms [1]. Also in domestic animals, leptospirosis causes, abortions, premature births, and stillbirths eventuate in world that reason economic detriment industry [1]. Leptospira has been consists of 24 sero groups and more than 300 serovars are close to 270 pathogenic [7] that can be segregated from different ecological niches and animal reservoirs. The genetic classification recently confirmed the existence of 35 species [9]. The prevalence of this disease is high among Ranchers and Smithers in Iran. According to studies in Razi Vaccine and Serum Research Institute, frequency of animal serum samples of suspected leptospirosis (Icteroheamorrhagiae serovar) in two provinces Gilan and Qom were 57.1 and $20 \%$ respectively. Icteroheamorrhagiae is more prevalence serovar in Hormozgan, too, with $45.5 \%$ frequency. Autumnalis, Pomona, and Sejroe Hardjo were reported in low incidence. Frequency of human serum samples of suspected leptospirosis in Gilan province is 12.1 percent. Sejroe Hardjo serovar was dominant in Ardebil province [10].

Many virulence factors were involved in the pathogenesis and infection of Leptospira bacteria, such as hemolysin, membrane proteins, lipopolysaccharides (LPS) and other surface proteins and external molecules $[11,12]$. The outer membrane proteins (OMP) of the bacterium, which are considered as antigen or binding targets for antibacterial antibodies, they act as receptors for different molecules of the host and thus an important role in the pathogenesis of these bacteria [13,14,15].

Diagnosis of leptospirosis has been confirmed by different methods such as Microscopic Agglutination Test (MAT) and Enzyme-Linked Immunosorbent Assay (ELISA). MAT is the standard technique for leptospirosis diagnosis which is carry out by incubating the patient serum with different live Leptospira serovars and recognizes by the grading of agglutination. The MAT needs to retain a collection of live strains. That is requires to alternative confirmation of each serovar in culture [16].

PCR and Real Time PCR techniques based on different genes such as 16srRNA and gyrB genes have successfully developed for the identification of pathogenic Leptospira [17].

Multi Locus Sequence Typing (MLST) was introduced to study strain taxonomy, global surveillance and in comparing evolution of the genus in Leptospira [18]. MALDI-TOF mass spectrometry was done for identification of Leptospira as a rapid and reliable method [19]. In different studies, several Leptospira antigens (rLipL32, rLipL41, rLigA, rLigB, rLipL21) were expressed in E. coli and evaluated in enzyme-linked immunosorbent assay [20, 21, 22]. Available commercial ELISA kits have a low sensitivity and specificity. On the other hand, there are several vaccines against different types of leptospira only for animals that can only reduce the risk of transmitting disease to human [23]. Therefore, finding new diagnostic methods is necessary to eliminate the limitations in standard tests. Enzyme-Linked Immunosorbent Assay (ELISA) using recombinant leptospiral antigens are sensitive techniques which have been expand as diagnostic methods for leptospiral infection $[16,24,25,26]$. Adenylate Cyclase protein belongs to outer membrane lipoproteins, which are found only in pathogenic and do not exist in non-pathogenic Leptospira [35]. In this study, we attempted to introduce the $\mathrm{AAcB}$ as a part of AGC protein, for detection of antibody titers in immunized herds also evaluation of vaccine performance by using ELISA test. 


\section{MATERIAL AND METHODS}

\section{Bioinformatics studies}

Multiple Sequence Alignment (MSA) of 242 complete coding sequences of AGC protein was done by MegAlign 5.00 DNASTAR Inc. software from 35 different serovars available in GenBank until 2.16.2019 conserved, variable regions, amino acid substitutions and other polymorphisms between different serovars were analyzed.

According to multiple sequence alignment of different serovars, one dominant pattern selected as a target sequence based on previous epidemiological studies of high prevalence pathogenic serovars (Icterohaemorrhagiae, SejroeHardjo) in Iran.

\section{Immune informatics studies}

T-cell and B-cell epitopes were predicted by Immune Epitope Database and Analysis Resource (https://www.iedb.org). Epitopes of MHC class I and II have been chosen according to HLA alleles (HLA$A^{*} 01: 01, \mathrm{HLA}-\mathrm{A}^{*} 02: 01, \mathrm{HLA}-\mathrm{A}^{*}$ 03:01 with Length 9) (DRB1*11, DRB1*13, DRB1*15, DRB1*4, DRB1*9) with consensus method and percentile rank of $\mathrm{MHCl}<0.5$ and $\mathrm{MHCll}<1$ were predicted respectively [27].

Kolaskar and Tongaonkar Antigenicity method was used for prediction. B-cell antigenic regions of AGC protein are intended to predict regions of protein that are likely to be recognized as epitopes in the context of a $B$ cell response. Antigenic index, hydrophobicity and surface probability were analyzed. Based on mentioned criteria, one peptide (region D259-R462) selected and named AcB.

\section{Codon optimization and DNA synthesis}

Nucleotide coding sequence of antigenic region D259-R462 of Adenylate Guanylate Cyclase protein was codon optimized according to codon table usage of $E$. coli by GenSmart ${ }^{\mathrm{TM}}$ Codon Optimization Tool (https://www.genscript.com/gensmart-free-gene-codon-optimization html). Two enzyme recognition sites EcoRl and Xhol were consider in 5' and 3' of DNA respectively. DNA synthesis was done by ShineGene BioTechnologies, Inc., Shanghai, China.

\section{Expression of fusion protein}

Recombinant plasmid was transformed into the Escherichia coli strain BL21-DE3 and cultured in 50ml 2YT media in presence of $50 \mu \mathrm{g} / \mathrm{ml}$ ampicillin. Induction was done when the optic density reached to 0.8. Concentration of IPTG between 0.1 to $0.5 \mathrm{mM}$ and two incubation temperatures $22^{\circ} \mathrm{C}$ and $37^{\circ} \mathrm{C}$ were compared. Expression of recombinant protein ( $\mathrm{rAcB}$ ) was confirmed by SDS-PAGE and commassie blue staining.

\section{Purification of $\mathrm{rAcB}$}

After induction, the cell from $50 \mathrm{~mL}$ bacterial cell culture was harvested by centrifugation at $5000 \mathrm{rpm}$ for 10 minutes. The cell pellets resuspend to $5 \mathrm{ml}$ PBS and sonicated 1 minute five times with one-minute interval (Hielscher Germany). Protease inhibitor PMSF in $0.1 \mathrm{mM}$ final concentration was added after sonication. Post sonication pellet (inclusion body) was washed five times by 1 to 5 molar Urea, $\mathrm{pH}=5.5$ after 1 hour shacking at $37^{\circ} \mathrm{C}$ for each one to remove non-target proteins. Finally, the pellet suspended in 6 to 8 molar urea by shaking at $37^{\circ} \mathrm{C}$ for 5 hours. Dialysis in PBS buffer was performed for 16 hours at room temperature for the removal of urea from solubilized protein. Presence of $r A c B$ in urea $6 \mathrm{M}, 7 \mathrm{M}$ and $8 \mathrm{M}$ were checked by SDSPAGE and commassie blue staining.

\section{Western Blotting}

Purified protein was electrophoresed into the 10\% reduced SDS-PAGE and transferred to a nitrocellulose membrane using the transfer buffer (194mM Glycine, 24mM Tris, $10 \%$ Methanol). The membrane was blocked with $2 \%(\mathrm{w} / \mathrm{v})$ bovine serum albumin (Sigma, Germany) in PBST, and incubated with anti-His tag HRP conjugated antibody (1:5000) (Thermo Fisher, Germany) for 1 hour at room temperature. After three washing steps by PBST, the rAcB protein band was developed by adding 4-Chloro-1-naphthol (Sigma, Germany). 


\section{Determination of protein concentration}

Concentration and yield of purified $\mathrm{rAcB}$ protein was achieved by Bradford method. Standard curve prepared based on BSA (bovine serum albumin) serial dilution from 0 to $10 \mu \mathrm{g}$ on XURU'S web server regression tools (www.xuru.org) by online linear regression method.

\section{Immunization of BALB/c Mice}

Five BALB/c mice injected subcutaneously with 20 micrograms of purified $\mathrm{rAcB}$ formulated with adjuvant montanide (ISA 70) (SEPPIC, France) in $0.5 \mathrm{ml}$ total volume three times in two weeks' interval. Four control groups PBS, Adjuvant-PBS, Adjuvant Alum, and Leptospira vaccine from Razi Vaccine and Serum Research Institute, Iran (www.rvsri.ac.ir) were considered. The blood samples were collected at before and 14, 28 and 42 days after injection.

\section{ELISA test}

96-well ELISA microplate was coated with $250 \mathrm{ng} /$ well rAcB and carbonate coating buffer $(\mathrm{pH}=9.6)$, then microplate incubated overnight at $4{ }^{\circ} \mathrm{C}$. Also plate was washed three times with PBST. After that coated plate was washed and first, incubated for 1 hour at room temperature with immunized mice sera diluted 1:100 in PBST, pH 7.5. After another washing, 100 $\mu$ Anti-mouse HRP-conjugated antibody 1:5000 in PBST was added to each well and incubated at $37^{\circ} \mathrm{C}$ for 1 hour then washed with PBST for five times. Then $50 \mu \mathrm{lMB}$ was added and incubated in dark place for 15 minutes and 2N H2SO4 was added to stop reactions. Quantification was performed using ELISA reader at wave length $450 \mathrm{~nm}$.

\section{Statistical analysis}

Collected data from ELISA plate were analyzed by paired samples T-test ( $n=10$, p-value 0.01 ) from five groups and box plot was designed by SPSS version 22.

\section{RESULTS}

\section{Bioinformatics results}

Twenty-two linear B-cell epitopes (score < 0.5), $21 \mathrm{MHCl}($ score $<50)$ and $67 \mathrm{MHCll}($ score $<1$ ) linear T-cell epitopes which were located in two antigenic regions in complete coding sequence of AGC protein were found by using The Immune Epitope Database and Analysis Resource (www.iedb.org). An antigenic site D259 to R462 with 203 amino acids length was selected for DNA construction [Fig 1].

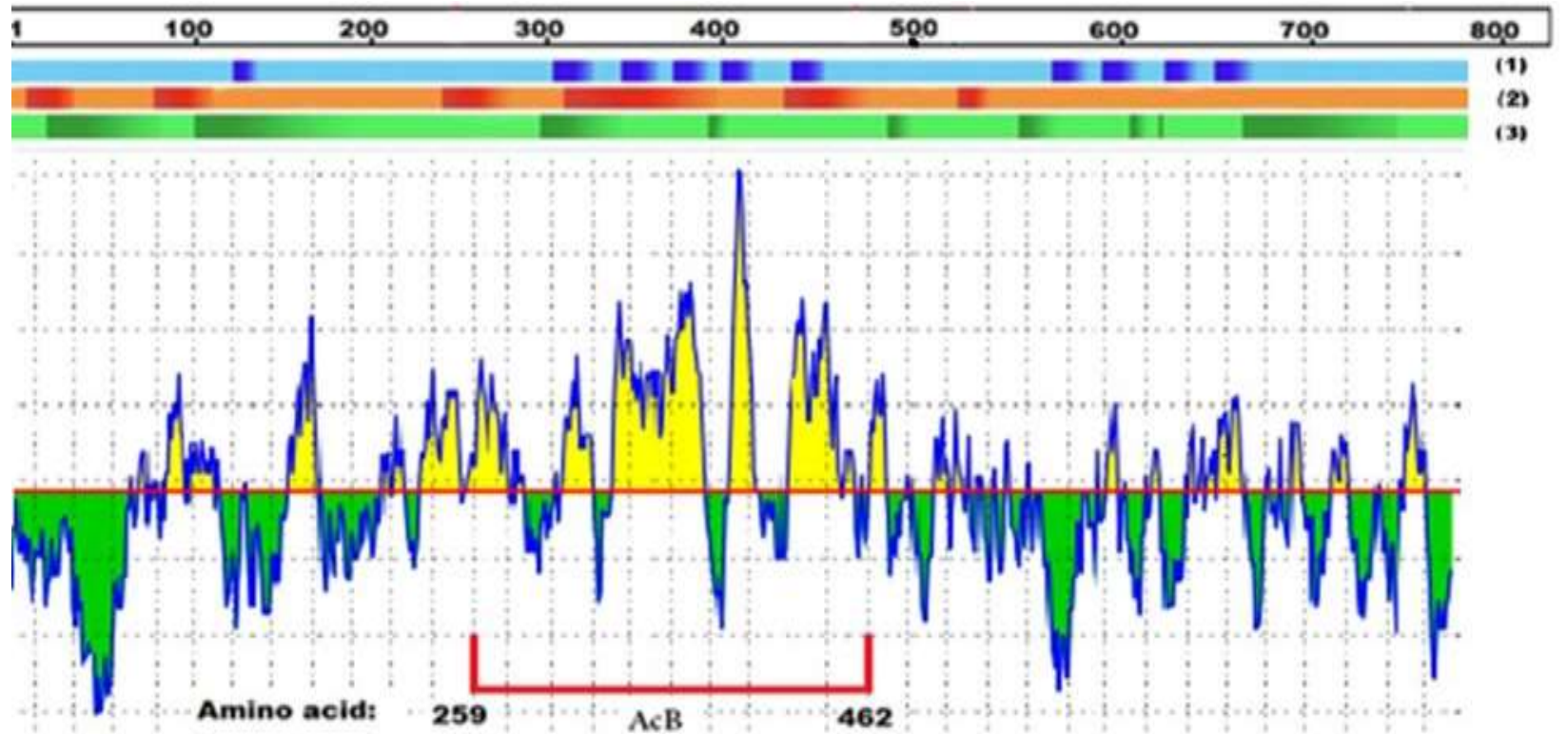

Figure 1. Schematic of AcB antigenic region (D259 to K462), T-cell and B-cell epitopes map in AGC protein based on the most epitopes. Lanes 1: positions of $\mathrm{MHCll}$ epitopes; 2: positions of $\mathrm{MHCl}$ epitopes; 3 : B-cell epitopes. Color density indicates the compression of epitopes in those regions. 


\section{Expression of rAcB in E. coli BL21 (DE3)}

Expression condition was optimized into $\mathrm{Bl} 21$ (DE3) strain of $E$. coli by $0.2 \mathrm{mM}$ IPTG after 16-hour incubation at $370 \mathrm{C}$. Expression of recombinant protein confirmed by $10 \%$ SDS-PAGE and commassie blue staining. Antigenic peptide $\mathrm{rAcB}$ was highly expressed as a fusion by $\operatorname{Tr} x$ tag sequence successfully in $E$. coli. A $38 \mathrm{kDa}$ Trx-AcB specific band was observed in bacterial lysate after induction [Fig.2]. Results demonstrated that $\mathrm{rAcB}$ was highly expressed as an inclusion body in non-soluble form [Fig.2].

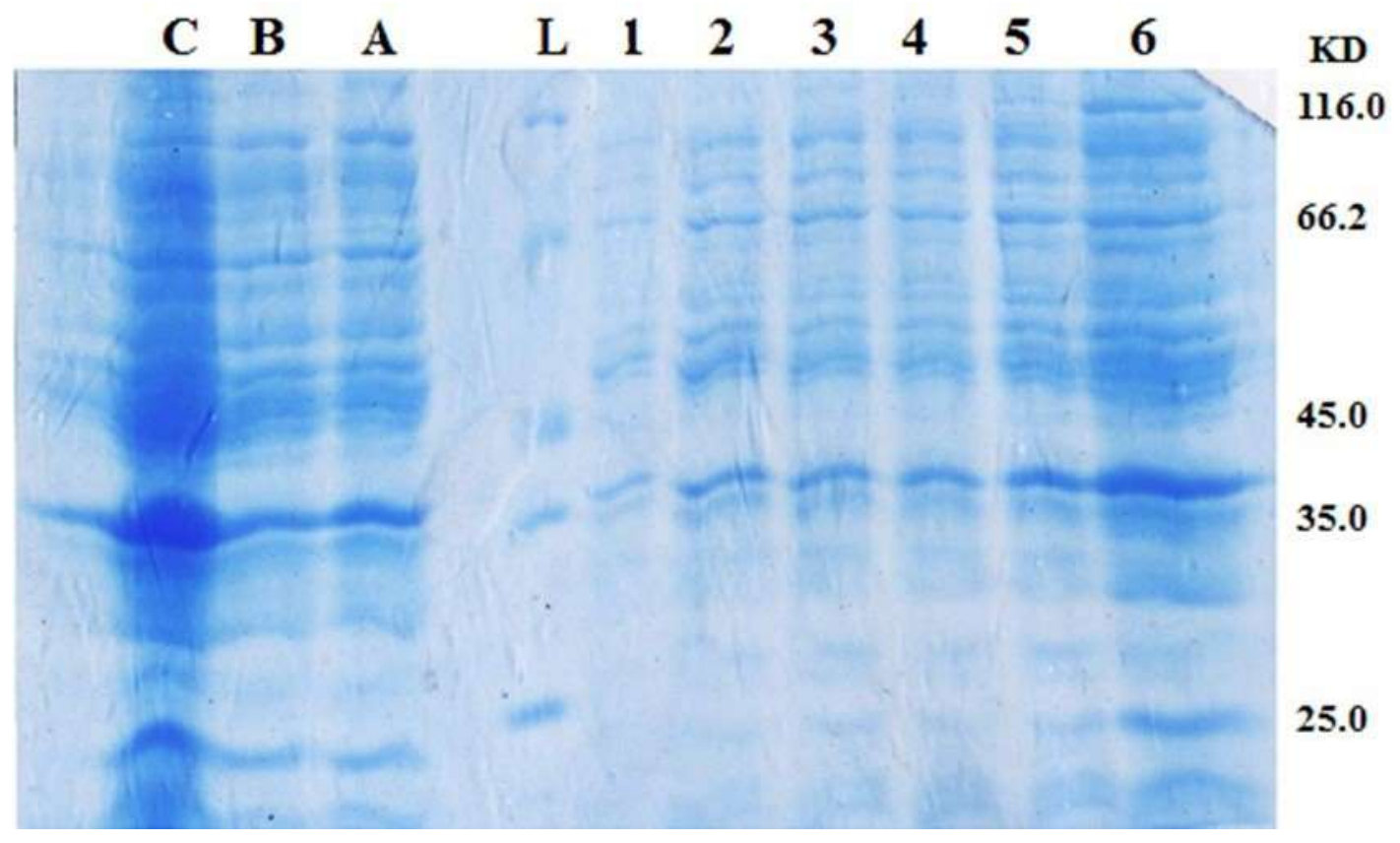

Figure 2. Electrophoresis of cell lysates derived from induction of $\mathrm{rAcB}$ protein with $0.2 \mathrm{mM}$ IPTG in to the $10 \%$ SDSPAGE in $10 \mathrm{~mA}$ for 16 hours. L: unstained protein MW marker (thermo scientific). Lanes 1 to 6 show the results of cell lysate from samples which were incubated for $0,1,2,3,4$ and 16 hours at $37 \mathrm{C}$. A: post sonication cell lysates. B: post sonication Supernatant, C: post sonication pellet.

\section{Purification and immune blotting of rAcB}

High amount of recombinant AcB $(514.2 \mathrm{mg})$ was purified from $1000 \mathrm{~mL}$ culture of $E$. coli surprisingly the serial washing with urea 1 to 5 molar resulted in high purity protein purification. The rAcB protein was observed in urea 6 to 8 molar [Figure 3A, lane 1, 2, 3].

To verify successful production of the $\mathrm{rAcB}$ protein, its fusion with the His-tag was confirmed by Western blotting. The results indicated that recombinant AcB-His-tag fusion protein created a band of about $38 \mathrm{kDa}$ with strong binding with the anti-His MAb. [Figure 3B, lane 2]. 


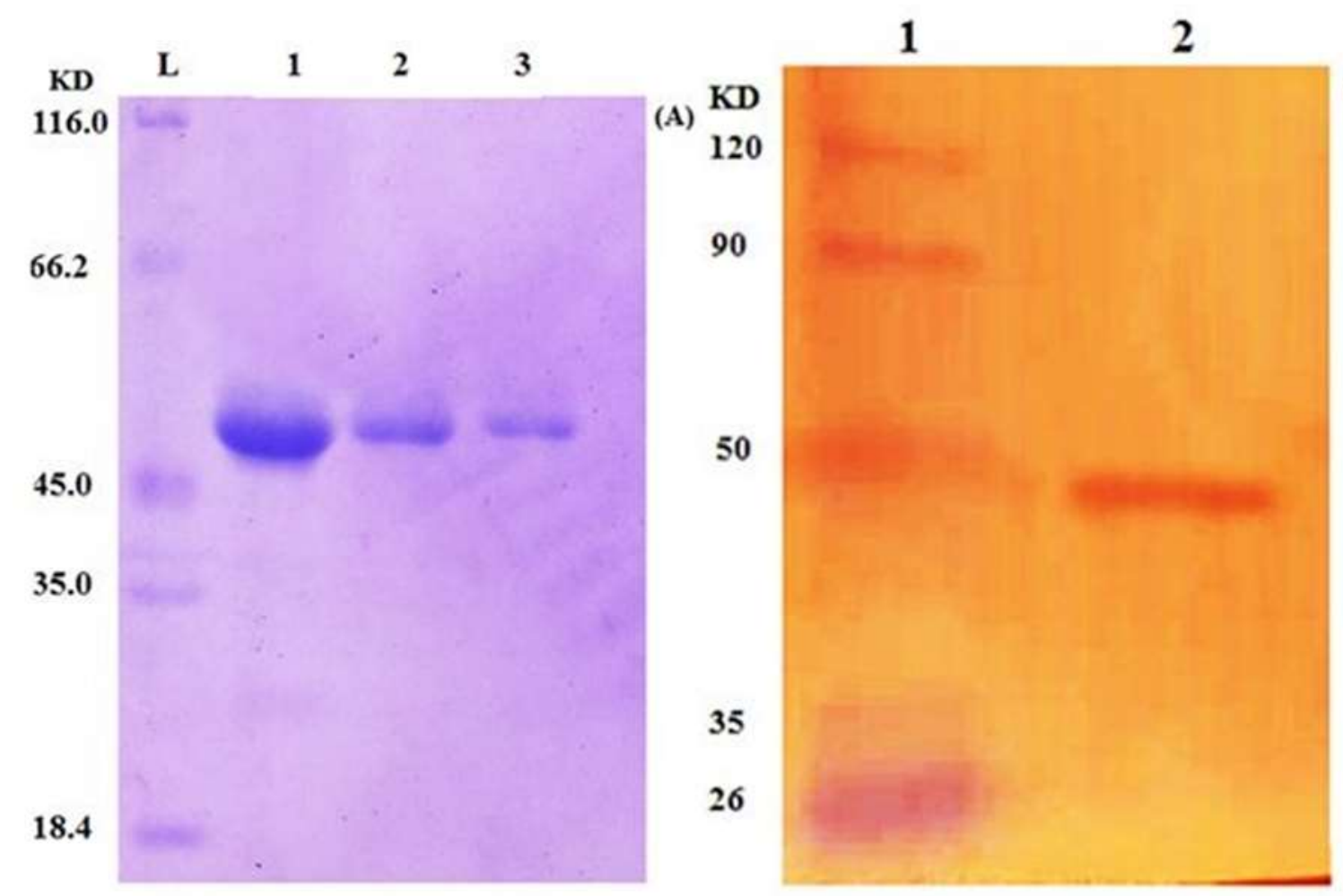

(B)

Figure 3. (A): SDS-PAGE of $\mathrm{rAcB}$ protein which was purified in gradient urea. Lanes 1: unstained protein MW marker (Thermo Fisher S cientific), 2: Purification of AcB protein with 6 molar urea, 3: Purification of AcB protein with 7 molar urea. 4: Purification of AcB protein with 8 molar urea. (B): Western blotting of purified rAcB by Anti His-Tag HRP conjugated antibody in nitrocellulose membrane. Lanes 1: prestained protein ladder (Thermo Fisher Scientific), 2: purified rAcB protein.

\section{Yield of rAcB purification}

Based on XURU'S online regression tools (www.xuru.org), with linear regression method $\mathrm{y}=47.31697024 \mathrm{X}-0.788$ formula was identified. Concentration of purified protein was calculated by Bradford assay method. Concentrations were $12,4.7$ and $9.01 \mathrm{mg} / \mathrm{ml}$ in purified recombinant protein from 6, 7 and 8 molar urea respectively. Totally, yield of purified recombinant protein was estimated $514.2 \mathrm{mg}$ per each $1000 \mathrm{ml}$ cell culture.

\section{Evaluation of rAcB in ELISA}

Concentration of $\mathrm{rAcB}$ for coating of ELISA microplate was $250 \mathrm{ng} /$ well. Antibody titer in blood samples of immunized mice were read in wave length $450 \mathrm{~nm}$. The prominently increasing of antibody level $(0.4$ to 1.20) were observed in immunized mice sera with $\mathrm{rAcB}$, while in control groups were 0.2 to 0.4 two weeks after last injection, [Figures 4,1$]$. Mice that received $\mathrm{rAcB}$ significantly had higher titers compare to control groups. Results demonstrated $\mathrm{rAcB}$ can detect antibodies from immunized mice whit Leptospira vaccine. [Figures 4,2] 

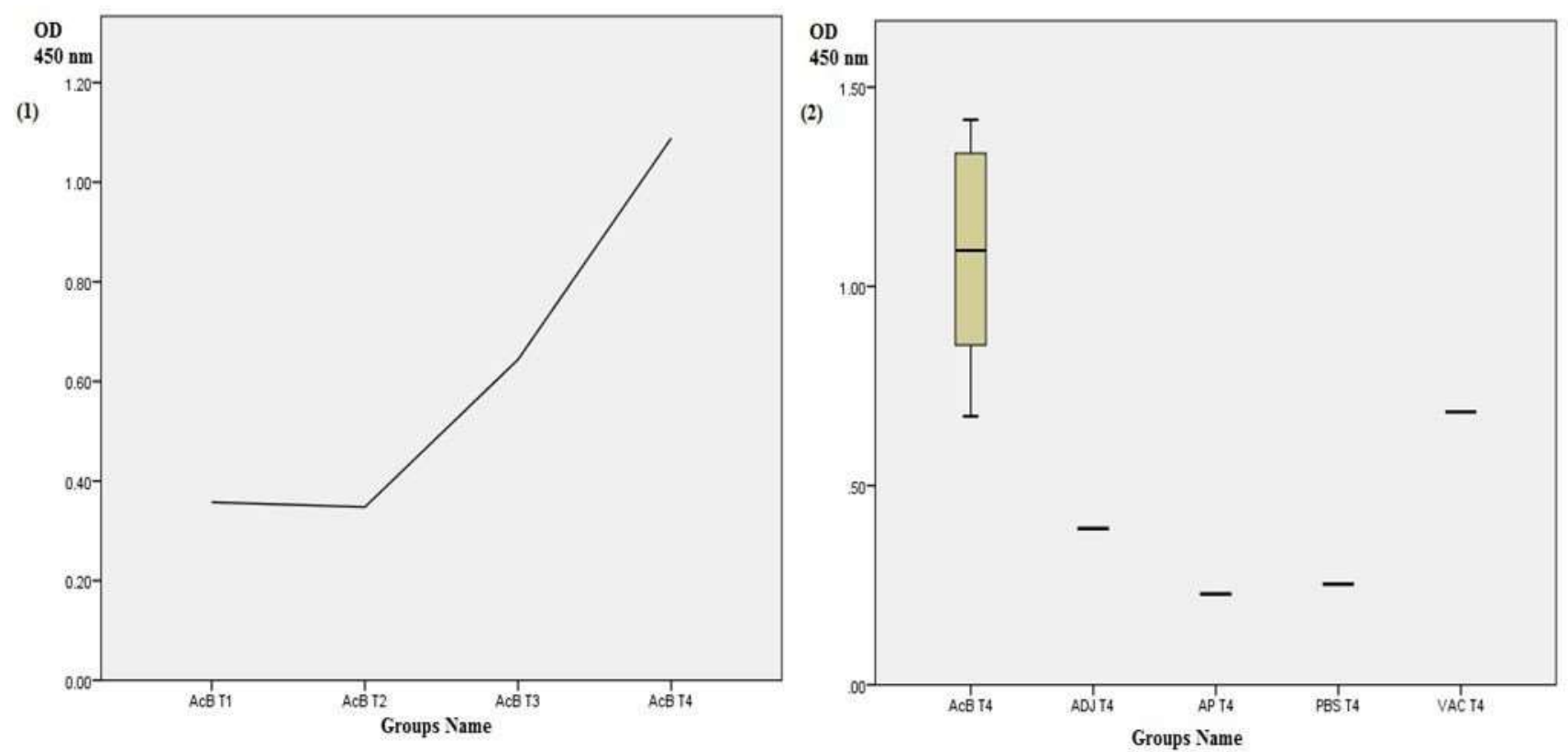

Figure 4. The diagram shows the ELISA results which was read at length at 450nm and analyzed by SPSS version 22 software.

(1): The graph indicates an increase in antibody level in blood samples of immunized mice by recombinant protein rAcB which was collected at the first day before injection to two weeks after the last injection.

(2): Comparison of antibody levels in different mice groups. AcB T4: group of immunized mice with recombinant AcB protein, ADJT4: group of injected mice with montanide adjuvant, APT4: the group of mice injected Adjuvant-PBS, PBST4: group of mice injected by PBS, VACT4: the group of immunized mice by leptospira vaccine. According to the graph, based on the $\mathrm{rACB}$ it was able to have a significant response to the control groups and was able to detect the vaccine.

\section{DISCUSSION}

Leptospirosis is an acute illness and spreads rapidly [1]. Animals and human can be infected through the urine of infectious animals or contaminate soil and water [11,28]. MAT is standard test for diagnosis of Leptospirosis, nevertheless; this technique unfavorable as it will take time and need labor [1]. Keeping in view the difficult of the MAT test as a standard technique, sensitive methods such as ELISA, using recombinant leptospiral antigens have been expand as diagnostic methods for leptospiral infection indifferent animal species. In ELISA test several samples analyzing simultaneously and faster than MAT test. Several recombinant proteins such as rLipL32, rLipL41, LigB, produced for recombinant ELISA for sero diagnosis of bovine leptospirosis [16, 29, 26, 30, 31]. Also recombinant LigA for equine leptospirosis [32] and a Leptospira OMP (Outer membrane protein) antigen, rLipL21, rLoa22 and rLipL32 for canine leptospirosis were evaluated as antigens for ELISA [33,34]. The aim of this study was Expression of recombinant peptide based on antigenic region (D259-R462) of Adenylate Guanylate Cyclase protein of Leptospira in E. coli and Evaluation of vaccine performance also detection of antibody titers in immunized herds by using ELISA test. AGC is a very important protein in regulating cell metabolism and is the membrane lipoprotein present only in pathogenic Leptospira [35]. The AGC protein contains 758 amino acids. Antigenic site D259-R462 (AcB) according to immune informatics study was selected and to increasing yield of protein expression codon optimization was done based on E. coli codon table usage. Nucleotide sequence was inserted into pET32a $(+)$ vector and $\mathrm{rAcB}$ was expressed as a fusion protein with thioredoxin (Trx). Fortunately, the rAcB protein from inclusion body was purified with high efficiency by the urea method. We found that urea purification method is a simple and low-cost with high efficiency technique. Several outer membrane proteins LipL32, rLipL21, rl-LipL21and LigANI of Leptospira were cloned and expressed in different hosts such as E. coli and P. pastoris. Purification yield of mentioned hosts were respectively 3 to $285 \mathrm{mg} / \mathrm{L}[36,37]$. In this study, purification of the recombinant protein resulted in high extent yield of $514.2 \mathrm{mg}$ per each $1000 \mathrm{ml}$ bacterial culture.

Results obtained from ELISA test showed that recombinant protein rAcB was able to produce high level of antibody in mice which were immunized (recombinant $A c B$ protein receiving group) and was suitable immunogenic. Amazingly analyzing data from ELISA demonstrated that rAcB which was coated to ELISA 
plate could be detected Leptospira antibody from immunized herds group with Leptospira vaccine. This is the first study to introduce AGC protein of Leptospira as a candidate antigen in ELISA to explore the feasibility of using them for detection of specific Leptospira antibodies in immunized animal.

\section{CONCLUSION}

The recombinant peptide AcB (D259-R462) which was produced in the $E$. coli has the ability to detect antibodies produced in vaccine-immunized animals, so this protein can be used to evaluate antibody levels in clinical trial of under developing vaccine and vaccination program.

Acknowledgments: This study was supported by Grant No. 2-18-18-109-96045-961026 from Razi Vaccine and serum Research Institute.

Conflicts of Interest: The authors declare no conflicting of interest.

\section{REFERENCES}

1. Levett PN. Leptospirosis. ClinMicrobiol Rev. 2001 14(2):296-326. PMID: 11292640

2. Bharti AR, Nally JE, Ricaldi JN, Matthias MA, Diaz MM, Lovett MA, et al. Leptospirosis: A zoonotic disease of global importance. Lancet Infect Dis. 2003 3:757-71. PMID: 14652202

3. Reis RB, Ribeiro GS, Felzemburgh RDM, Santana FS, Mohr S,Melendez AXTO, Adriano Q, Andre'ia CS, Romy RR, Wagner ST, Marı'lia SC, Mitermayer GR, Albert IK. Impact of environment and social gradient on Leptospira infection in urban slums. PLoSNegl Trop Dis. 2008; 18:2 doi:10.1371/journal.pntd.0000228.

4. Trueba G, Zapata S, Madrid K, Cullen P, HaakeD.Cell aggregation: a mechanism of pathogenic Leptospira to survive in fresh water. IntMicrobiol. 2004; (7):35-40.

5. Djadid ND and Ganji Z F.A simple and rapid nested polymerase chain reaction-restriction fragment length polymorphism technique for differentiation of pathogenic and nonpathogenic Leptospira spp. Diagnmicrobiol infect dis. 2009;63(3):251-6.

6. Ellis WA. Animal leptospirosis. CurrTrpMicrobiollmmunol. 2005; 387:99-137. doi: 10.1007/978-3-662-45059-8_6.

7. Picardeau M. Virulence of the zoonotic agent of leptospirosis: still terra incognita? Nat VerMicrobiol. 2017; 15: 297307. doi: 10.1038/nrmicro.2017.5.

8. Bovet $P$, Yersin $C$, Merien F, Davis $C E$, Perolat $P$. Factors associated with clinical leptospirosis: a population-based case- control study in the Seychelles (Indian Ocean). Int J Epidemiol. 1999;28:583-90.

9. Thibeaux R, Girault D, Bierque E. Soupé-Gilbert M E, Rettinger A, Douyère A, Meyer M, Iraola G, Picardeau M, Goarant C Biodiversity of Environmental Leptospira: Improving Identification and Revisiting the Diagnosis. Front Microbiol. 2018; $1: 816$. doi: 10.3389/fmicb.2018.00816.

10. Khaki P, Roohi Z, MoradiBidhendi S. Application of micro agglutination test in detecting serovars of leptospira. J GorganUni Med Sci. 2014;16(3):99-105.

11. Faine S, Adler B, Bolin C, PerolatP.Leptospira and Leptospirosis.Melbourne: MedScience, 1999

12. Cullen PA, Haake DA, Adler B. Outer membrane proteins of pathogenic spirochetes. FEMS Microbiol Rev. 2004; 28:291-318.

13. Luo Y, Frey EA, Pfuetzner RA, Creagh AL, Knoechel DG, Haynes CA, et al. Crystal structure of enteropathogenic Escherichia coli intimin-receptor complex. Nature 2000; 405:1073-7.

14. Werts C, Tapping RI, Mathison JC, Chuang TH, Kravchenko V, Saint Girons I, et al. Leptospiral lipopolysaccharide activates cells through a TLR2-dependent mechanism. Nat Immunol 2001; 2:346-52. [PubMed: 11276206]

15. Haake DA, Matsunaga J. Characterization of the leptospiral outer membrane and description of three novel leptospiral membrane proteins. Infect Immun 2002;70:4936-45. [PubMed: 12183539]

16. Hartleben CP, Leal FM, Monte LG, et al., Serological analysis byenzyme-linked immunosorbent assay using recombinant antigen LipL32 for the diagnosis of swine leptospirosis. CurrMicrobiol. 2013;66:106-9.

17. Slack AT, Symonds ML, Dohnt MF, Smythe LD. Identification of pathogenic Leptospira species by conventional or real-time PCR and sequencing of the DNA gyrase subunit B encoding gene. BMC Microbiol. 2006 Oct 27;6:95. doi: 10.1186/1471-2180-6-95.

18. Guglielmini J, Bourhy P, Schiettekatte O, Zinini F, Brisse S, Picardeau M. Genus-wide Leptospira core genome multilocus sequence typing for strain taxonomy and global surveillance. PLoSNegl Trop Dis. 2019 Apr 26;13(4):e0007374. doi: 0.1371/journal.pntd.0007374. eCollection 2019 Apr.

19. Djelouadji Z1, Roux V, Raoult D, Kodjo A, DrancourtM.Rapid MALDI-TOF mass spectrometry identification of Leptospira organisms. Vet Microbiol. 2012 Jul 6;158(1-2):142-6. doi: 10.1016/j.vetmic.2012.01.028. Epub 2012 Feb 3. 
20. Chen HW, Zhang Z, Halsey ES, Guevara C, Canal E, Hall E, Maves R, Tilley DH, Kochel TJ, Ching WM. Detection of Leptospira-specific antibodies using a recombinant antigen-based enzyme-linked immunosorbent assay. Am J Trop Med Hyg. 2013 Dec;89 (6):1088-94. doi: 10.4269/ajtmh.13-0041. Epub 2013 Oct 28.

21. Deneke Y, Sabarinath T, Gogia N, Lalsiamthara J, Viswas KN, Chaudhuri P. Evaluationof recombinant LigB antigen-based indirect ELISA and latex agglutination test for the serodiagnosis of bovine leptospirosis in India. Mol Cell Probes. 2014 Aug;28(4):141-6. doi: 10.1016/j.mcp.2014.01.001.

22. Joseph S, Thomas N, Thangapandian E, Singh VP, Verma R, Srivastava SK. Evaluation and comparison of native and recombinant LipL21 protein-based ELISAs for diagnosis of bovine leptospirosis. J Vet Sci. 2012 Mar;13(1):99101. doi: 10.4142/jvs.2012.13.1.99.

23. Chen TZ.. Development and present status of leptospiral vaccine and technology of vaccine production in China. Jap. J Bacteriol. 1985: 40, 755-62

24. Tomich RGP, Bomfim MRQ, Koury MC, Pellegrin AO, Pellegrin LA, Ko Al, et al. Leptospirosis serosurvey in bovines from Brazilian Pantanal using IgG ELISA with recombinant protein LipL32 and microscopic agglutination test. Brazilian J Microbiol. 2007;38(4):674-80. http://dx.doi.org/10.1590/ S1517-83822007000400017

25. J. Lizer, M. Grahlmann, H. Hapke, S. Velineni, D. Lin, B. Kohn, Evaluation of a rapid IgM detection test for diagnosis of acute leptospirosis in dogs, Accepted, 2017 Jan 30; doi: 10.1136/vr.104134

26. Mariya R, Chaudhary P, Kumar AA, Thangapandian E, Amutha R, Srivastava SK. Evaluation of a recombinant LipL41 antigen of Leptospirainterrogansserovarcanicola in ELISA for serodiagnosis of bovine leptospirosis. 2006 Nov;29(5-6):269-77. Epub 2006 Sep 18. DOI: 10.1016/j.cimid.2006.06.007

27. Yari $F$, Bagheri N, ZamanVaziriM,SobhaniM,Sabaghi F, Talebian A. HLA DRB1 polymorphism in the Iranian population, Iranian Blood Transfusion Organization - Research Center, 2007 Sep 18.

28. Adler B, Moctezuma AP. Leptospira and leptospirosis. Vet Microbiol.2010;140(3):287-96.

29. Maria Rosa QuaresmaBomfim , Albert Ko , Matilde Cota Koury, Evaluation of the recombinant LipL32 in enzymelinked immunosorbent assay for the serodiagnosis of bovine leptospirosis, 2005 Elsevier B.V. All rights reserved.doi:10.1016/j.vetmic.2005.05.002

30. Deneke Y, Sabarinath T , Gogia N , Lalsiamthara J , Viswas KN , Chaudhuri P4. Evaluation of recombinant LigB antigen-based indirect ELISA and latex agglutination test for the serodiagnosis of bovine leptospirosis in India. 2014 Aug;28(4):141-6. doi: 10.1016/j.mcp.2014.01.001. Epub 2014 Jan 18.

31. Nagalingam M , Thirumalesh SR, Kalleshamurthy T, Niharika N, Balamurugan V, Shome R, Sengupta PP , Shome BR , Prabhudas K, Rahman H . Comparative evaluation of recombinant LigB protein and heat-killed antigen-based latex agglutination test with microscopic agglutination test for diagnosis of bovine leptospirosis. 2015 Oct:47(7):1329-35. doi: 10.1007/s11250-015-0867-7. Epub 2015 Jun 12.

32. Yan W, Saleem MH, McDonough P, McDonough SP, Divers TJ, Chang YF. Development of an enzyme-linked immunosorbent assay using a recombinant LigA fragment comprising repeat domains 4 to 7.5 as an antigen for diagnosis of equine leptospirosis. 2013 Aug;20(8):1143-9. doi: 0.1128/CVI.00245-13. Epub 2013 May 29

33. Sathiyamoorthy A, Selvaraju G, Palanivel KM, Srinivasan AP. Development of indirect enzyme-linked immunosorbent assay for diagnosis of canine leptospirosis. 2017 May;10(5):530-535. doi: 10.14202/vetworld.2017.530-535. Epub 2017 May 20

34. Ye C, Yan W, Xiang H, He H, Yang M, ljaz M, Useh N, Hsieh CL, McDonough PL, McDonough SP, Mohamed H, Yang Z , Chang YF . Recombinant antigens rLipL21, rLoa22, rLipL32 and rLigACon4-8 for serological diagnosis of leptospirosis by enzyme-linked immunosorbent assays in dogs. 2014 Dec 19;9(12):e111367.doi: 10.1371/journal.pone.0111367. eCollection 2014

35. Grassmann AA, Kremer FS, Santos JC, Souza JD, Pinto LS, McBride AJ. Discovery of novel leptospirosis Vaccine candidates Using reverse and structural Vaccinology. Published: 2017 April 27, doi: 0.3389/fimmu.2017.00463

36. Hartwig DD, Oliveira TL, Seixas FK, Forster KM, Rizzi C, Hartleben CP, McBride AJ, Dellagostin yeastPichiapastoris. 2010 Dec 6;9:98. doi: 10.1186/1475-2859-9-98

37. Barkó S, Szatmári D, Bódis E, Türmer K, Ujfalusi Z, Popp D, Robinson RC, Nyitrai M . Large-scale purification and in vitro characterization of the assembly of MreB from Leptospirainterrogans. 2016 Sep;1860 (9):1942-52. doi: 10.1016/j.bbagen.2016.06.007. Epub 2016 Jun 11. 